\title{
Christelik-nasionale onderwys in die nuwe Suid-Afrika
}

\author{
H G van der Westhuizen \\ Hervormde Teologiese Opleiding
}

\begin{abstract}
Christian national education in the new South Africa

The Dutch Reformed Church of Africa (Nederduitsch Hervormde Kerk van Afrika), as a People's Church, according to Scripture takes an intense interest in the education of the nation's youth. According to educational principles, the best school is one in own cultural milieu. The negative reports on multicultural education received from various countries are disquieting for the Church. Consequently, it is necessary to contemplate different options for maintaining Christian national education in a new era.
\end{abstract}

\section{INLEIDING}

Die werklikheidsbesef van die Christen-Afrikaner word gevorm deur die wêrelde waarin hy leef: die geloofswêreld, die eievolkswêreld en die wêreld van die moderne mensdom. Opvoedende onderwys sal die kind tot geïntegreerde ontplooiing van hierdie drievoudige werklikheidsbesef moet begelei (Van der Westhuizen 1966:137139).

Met die volksontbening van die Afrikaner (Van der Westhuizen 1981:18-36) word ten opsigte van die onderwys 'n sleutelbeen van ons volk gebreek (Van der Westhuizen 1981:28). Die opvoedkundige onderwys as begeleiding tot die genoemde drievoudige werklikheidsbesef is alleen moontlik in ideale omstandighede soos wanneer ons volk in besit en beheer van sy eie volkstrukture is.

Omdat die Afrikanervolk in die nuwe Suid-Afrika klaarblyklik nie oor die nodige volkstrukture sal beskik nie, moet die opsies wat ten opsigte van die onderwys vir ons bestaan, betyds oorweeg en ten beste benut word.

Die een opsie veronderstel dat die onderwys alleen by die verkryging en handhawing van die eie soewereine volkstruktuur in die reine kan bly. Om hierdie opsie uit te oefen is daar twee moontlikhede. Eerstens moet probeer word om ten spyte 
van die verslegtende omstandighede vir ons volk tog 'n soewereine volksregering onder min of meer status quo-omstandighede te handhaaf. Of dit op die lange duur en die miskien nie te lange duur nie, haalbaar sal wees, raak 'n politieke en militêre kwessie. Daaraan word dus nie hier verder aandag gegee nie.

Die tweede moontlikheid vir 'n soewereine volksbestaan is die amputasiegedagte. Hiervolgens moet die gebeente van ons volk op 'n bepaalde kleiner geografiese gebied ingetrek word en die geografiese res moet afgesny word. Indien dit haalbaar is, sou die volksonderwys natuurlik daarby baat. Omdat ook hierdie moontlikheid 'n suiwer politiek-staatkundige volksonderneming is, word die bespreking daarvan gelaat.

Terwyl die onderwysopsies as sodanig nou verder aan die beurt moet kom, moet egter onthou word dat 'alle gepraat en geskryf albasterspel met ronde woorde [is] indien dit nie deur die politiek werklik tot gesonde struktuurvorming en -handhawing lei nie' (Van der Westhuizen 1981:32).

\section{WESE VAN ONDERWYS}

\subsection{Lewensbeskouing}

Dit is opvoedkundig verkeerd om 'n eenheidstaat waarin geen diskriminasie sou wees nie, te propageer. Realisties gesien is daar die verskillende lewensbeskouings, verskillende kulture en tradisies, verskillende waardestelsels en so meer wat in 'n groot mate ook deur verskillende fisiese eienskappe van volke of etniese groepe in Suid-Afrika verteenwoordig word. Dit is eenvoudig 'n onmoontlikheid om geen diskriminasie in 'n eenheidstaat toe te pas nie. 'As daar geen diskriminasie op grond van kleur sou wees nie, is daar diskriminasie teen lewensbeskouing' (Van der Westhuizen 1981:25).

Selfs die beskouing van die wese van onderwys kan nie 'n kleurlose neutrale objektiwiteit wees nie. Die definisie van onderwys word deur die verskillende lewensbeskouings gefundeer. 'Lewensbeskoulike differensiasie is trouens 'n gesonde verantwoordbare pedagogiese beginsel' (Schoeman 1991:18). Die groot opvoedkundige, prof Coetzee (1969:18) sê: 'En ons het reeds daarop gewys dat die grondvrae van ons lewênsopvatting ook maar die grondvrae van ons mensbeskouing is. En ek wil dan die verband nader lê: Dit is ook maar die grondvrae van ons opvoeding van die mens.'

Die sekularistiese lewensbeskouing sou onderwys alleen sien as 'n tegniese toerusting om 'n volwasse bestaan in die moderne wêreld te voer.

Die Afrikaner of enige volksbewuste se onderwys sal as opvoedende onderwys 'n kulturele grondmotief hê: 
Onderwys en opvoeding is etnies-kultureel in alle fasette bepaald; onderwys en opvoeding is nie slegs die vergestalting van die eie lewensopvatting in die kind as opvoedeling nie maar is ook die oordrag van die waardevolle in die eie kultuur aan die volgende geslag, en ten derde is onderwys en opvoeding self ook kultuurskeppend.

(Van der Walt 1985:132)

Die godsdienstige mens sien nog 'n dieper dimensie in die onderwys, naamlik 'n religieuse grondmotief:

Die onderwys is gefundeer in en vloei voort uit die religieuse grondmotief. Elke kultuurgemeenskap is gebonde aan sy Oorsprong of oorsprong waardeur sy totale denke en handelinge (66k sy opvoedende onderwyshandelinge) gerig en bepaal word. Die eie religieuse grondmotief wat vir die eie opvoedende onderwys bepalend is, is onversoenbaar met dié van 'n ander. Die verwesenliking van die religieuse grondmotief in die menslike doen en late vind vergestalting in 'n bepaalde lewens- en wêreldbeskouing. Lewensbeskoulik ongedifferensieerde onderwys in sogenaamde neutrale geïntegreerde openbare skole moet dus afgewys word.

(Barnard 1985:19)

\subsection{Die Bybel}

Die mens is nie eensaam geskep nie, maar in gemeenskap. Die gesin is die mees primêre en basiese samelewingsverband. Wat God aan Adam se, moet volledig en korrek aan Eva oorgedra word. Wat die ouers weet, moet aan die kinders oorgedra word. Dikwels word in die Bybel 'n leer-onderwys-opvoedingsopdrag aan ouers gegee. (Dit is nie nodig dat ons nou hier gedeeltes van belang soos Eks 20:12; Deut 6:6,7; Ps 78:5-7; Ef 6:1-2; Kol 2:8; 3:20-21 ens nagaan nie.)

Die geloofsiening van die gesin maak die gesin die primêre basis nie net van die kerk as gesinskerk nie, maar ook van die onderwys. Dit is immers vanweë die feit dat die mens nie deur instink kan lewe nie maar via opvoeding moet leef, dat hy alleen deur opvoeding in gesinsverband liefde, sekuriteit en dissipline kan ontvang (Van der Westhuizen 1977:24-37).

Die skool as gesinsverankerde verlengstuk van die onderwys in die samelewing onder koördinering en inspraak van die staat, moet dus die Christelike- en volkswaardes van die gesinne daarby betrokke weerspieël. 'Die skoolgebou en -terrein [is] 'n spieëlbeeld van die gemeenskap in wie se diens dit staan, en [moet] met die leefwêreld van die kind verband hou' (Barnard 1985:18). 'Egte en ware opvoedende onderwys is slegs moontlik as dit geskied in korrelasie met die volkskultuur asook 
met die lewens- en wêreldbeskouing wat in die opvoedeling se lewensmilieu aangetref word' (Barnard 1985:25). President Steyn het, opvoedkundig gesien, alreeds tereg gesê: 'Hou die kind in die hand. Gee hom nie af nie, selfs nie aan die regering nie, voor julle nie weet wat hulle met hom gaan doen nie' (vgl Van der Westhuizen 1981:28).

Die volgende aanhaling is vir ons van besondere belang: 'Daarom is dit ook belangrik dat elke Christelike huis sal toesien dat hy sy stempel op enige sekondère samelewingsverband wat aan die opvoeding van sy kinders meewerk, sal afdruk...' (Niemann 1985:57).

Die besondere belang van hierdie verpligting wat op ons gesinne, die huisgemeentes, gele word en daarmee ook op die Nederduitsch Hervormde Kerk, is geleë in 'n onderneming teenoor God. By die doop van ons kinders is 'n belofte aan God gedoen, 'n belofte waaraan die gemeenskap van gelowiges aandadig is. Hierdie belofte om die verbondskind faseologies geloofsonderrig te gee 'en te laat onderrig' (Diensboek 1987:58) impliseer dat ons sal toesien dat onderwysers en leerinhoude 'met 'n Christelike gees deursuur sal word' (Niemann 1985:57).

Die begrip 'Christelik-nasionaal' is 'n samevatting van die volkseie kultuurgoedere waarvan die Christelike geloof die binnedringende gees is. Omdat 'Christelik' 'n gediversifiseerde en gedevalueerde begrip geword het, het die begrip 'Christeliknasionaal' ook in ' $n$ vaste tegniese term 'n reformatoriese konfessionele betekenis (Van der Walt 1985:33). In die toekoms sal die 'nasionaal' dalk ook uitfaseer word: 'Die begrip Christelik-volkseie onderwys beteken min of meer dieselfde as Christelik-nasionale onderwys, maar eersgenoemde begrip sal in 'n nuwe Suid-Afrika verkiesliker wees omdat die begrip nasionaal mettertyd 'n betekenisverruiming ondergaan het' (Schoeman 1991:18).

\subsection{Gesinsgebonde onderwys}

Hiermee word vanselfsprekend nie bedoel dat die onderwys waarby kerk en staat ook belang het, elke detail van elke gesin moet verreken nie. Die negatiewe, foutiewe, afwykende en tekortkomende van 'n gesin en gesinne moet juis deur kerk en staat (Van der Walt et al 1985:265-269) uit die onderwys geweer word. Opvoedkundiges is dit eens dat 'die skool die opvoeding in die gesin [moet] aanvul en mag nie die huis of die lewensbeskouing van die ouer vervang nie' (Niemann 1985:58).

Die algemene eienskappe van gesinne ten opsigte van hulle geloof, kultuur en tegniese wèreld, moet in die onderwys verreken word.

Dit is 'n algemene opvoedkundige beginsel dat primêre onderwys in die moedertaal moet plaasvind. In ons geval moet ons skole dus Afrikaansmedium wees. 
Die Afrikaanse volk waaraan ons behoort, het sy eie geskiedenis, geskiedenisbenadering en geskiedenisbeskouing. Dit moet in sy onderwys vakmatig en onderwyskundig ingebou word.

Die wêreld van geleerdheid, tegniek en ander moderniteite vereis natuurlik 'n bytydse onderwyskurrikulum. Ons gesinne en ons volk leef eenvoudig in die wêreld wat oorgaan na die een en twintigste eeu. 'n Onderwys wat hierdie feit egter tot 'n verterende god verhef, sal sowel die taal en verlede van ons volk as ons volksbestaan verslind. So 'n god verdra ook nie die God van die Bybel nie. Die belangrikste is egter dat die lewende God wat geen ander gode voor sy aangesig toelaat nie, in ons huise en gemeentes gedien word - en ook in ons skole gedien moet word.

Swart gesinne en blanke gesinne, al woon hulle in dieselfde gemeenskap, al werk hulle binne dieselfde arbeidstruktuur, behoort aan verskillende volke. Hulle verskil histories, kultuurmatig, karaktermatig en grootliks ook godsdienstig. Mengskole is reeds om opvoedkundige redes uit Christelik-nasionale oogpunt 'n volslae onmoontlikheid.

\section{MENGSKOLE}

Opvoedkundiges wat nie polities nie maar opvoedkundig georiënteer is, keur mengskole af:

Vanweë besondere omstandighede sal die skool nie met die hele breë gemeenskap kan assosieer en dit regstreeks bedien nie, maar'n bepaalde sektor van die gemeenskap sal hom op godsdienstigideologiese gronde en vanweë kultuuretniese oorwegings rondom 'n bepaalde skool verenig.

(Van der Walt 1985:126)

Tog is daar orals in die wêreld pogings om mengskole in stand te hou - 'n mode wat weens die huidige politieke rigting in Suid-Afrika waarskynlik die voorland van die nuwe Suid-Afrika is.

\subsection{Globalisme}

Die motivering vir mengskole is hoofsaaklik in 'n lewensbeskouing geleë wat die mensdom as een broederskap buite Christus om wil herstel. Opvoeding en onderwys word as instrument gebruik om volgens Pienaar 'n 'gelykskakelingsproses waar identiteit opgaan in algemeenheid [globalism]' te realiseer (Louw 1983:v). Omdat dit ' $n$ heidens-humanistiese bedreiging is, het die kerk uit 'n kersteningsoogpunt alle belang hierby.

In Amerika het daar tussen 1880 en 1915 sowat veertig miljoen immigrante uit sowat veertig lande met verskillende tale en lewensbeskouings hulle gevestig. In 'n 
Amerikaniseringsproses is gepoog om hierdie probleem van 'n onmoontlike getal identiteite op te los. Omdat die Amerikanisering uit 'n kulturele imperialisme met euwels soos uitbuiting en oorheersing bestaan het, het die reaksie op die melting potteorie (MP) uitgeloop.

. Die teorie van die MP

...het sy ontstaan te danke aan 'n toneelstuk The Melting Pot wat deur 'n Britse Jood, Israel Zangwill, geskryf is en in 1908 in New York opgevoer is. In die toneelstuk word die samesmelting van 50 volksgroepe met 50 verskillende tale en geskiedenisse in die vooruitsig gestel. Uit hierdie samesmelting sou dan 'n nuwe en meer verhewe Amerikaanse volk ontstaan....

(Louw 1983:19)

Die een-nasie-bou van die nuwe Suid-Afrika het dieselfde grondslag. Die MPonderwys het egter misluk omdat ook die onderwysers nie in staat was om die verskillende kulture bymekaar te bring nie. 'Hy het sy eie kultuurgroep beter verstaan en bevoordeel...' (Heyns 1985:139).

Die MP-onderwys wat in Amerika reeds misluk het, is met die multicultural education-idee (ME) vervang (Heyns 1985:140). Die ME klink aanvaarbaar asof die verskillende kulture as eiesake 'n erkenning vind te midde van gemeenskaplike sake. Maar dit is 'duidelik dat die term ME baie misleidend is en maklik verstaan kan word asof daarmee bedoel word dat verskillende kulture in en deur die opvoeding in so 'n mate erken en gerespekteer word dat elkeen tot sy reg kan kom, terwyl dit juis nie die geval is nie' (Louw 1983:5).

Dit blyk dat ME '[that] rejects segregation of any kind' op niks anders uitloop nie as interkulturele onderwys (Louw 1983:6). Ook hierdie poging wat in konflik is met opvoedkundige beginsels, misluk omdat 'dit uiters moeilik vir 'n onderwyser [is] om hom volkome met meer as een kultuur te vereenselwig' (Heyns 1985:140).

Van die vernaamste ander probleme rondom ME is (Heyns 1985:140):

* Akademiese prestasie verlaag.

- Die selfbeeld van leerlinge word nie verbeter nie.

- Rasseverhoudings het nie verbeter nie en rassespanning het nie afgeneem nie.

* Dissipline op die skoolterrein en in die klaskamer verswak.

Die ME-beginsels werk nie in die VSA nie, ook nie in Brittanje, Australië en Israel nie (Heyns 1985:139, 140). 'n Sending van die Transvaalse Onderwysdepartement wat van 6 April tot 5 Junie 1979 na die buiteland was, het bevind dat sowel die ME as metodes soos busing om die ME te help implementeer, grootliks misluk: 
Dit moet duidelik gestel word dat wrywing nie net tussen Blankes en Swartes voorkom nie en dat 'busing' nie net die vervoer van Swartes na blanke gebiede is nie. Diskriminasie op grond van etniese verskille is 'n wêreldwye verskynsel. Om die hele mensheid in 'n eenheid te wil saamsnoer, is 'n onrealistiese ideaal, volgens die ondersoekspan van die Transvaalse Onderwysdepartement wat 'n ter plaatse studie gemaak het van alle groot Westerse lande asook Israel. As gevolg van die stelsel van 'busing' het Blankes uit verset daarteen, die stedelike gebiede verlaat en na die nuwe woonbuurte verhuis. Dit het meegebring dat die ouer woonbuurte deur anderkleuriges (Swart en Geles) beset is.

(Coetzee sa:18)

Kunsmatige metodes om byvoorbeeld deur middel van 'busing' ME te implementeer, hou gewoonlik baie nadele in:

As gevolg van 'busing' word kinders onnodig blootgestel aan gevaar; tydverkwisting met reis; geldverkwisting wat andersins beter aan onderwys bestee kon word; leerlinge is trots op hul eie omgewing en word in ander ingedwing (trots vir eie word vernietig); natuurlike vriendskappe word verbreek op 'n onnatuurlike wyse; dit los nie uitsakking en jeugmisdaad op nie en dit veroorsaak die uitwyking van Blankes uit digbewoonde gebiede.

(Coetzee sa: 19)

Die De Lange-verslag oor onderwys wat die grondslag vir onderwys in die nuwe Suid-Afrika is, beveel feitlik al die mislukte komponente van die ME aan (Louw 1983:74-125).

\section{REGERINGSBELEID}

\subsection{Onstabiel}

Die onderwysbeleid is nie meer soos in die verlede konstant nie. In die verlede het elke provinsie wel sy eie onderwysdepartement gehad, maar die onderwysgrondslae en -oogmerke het ten spyte van kurrikulumverskille tog 'n eenheid geopenbaar. Daarby was daar onderwysdifferensiasie, ook om vir onderwys aan Swartes voorsiening te maak. Dat veral by laasgenoemde vele probleme en agterstande bestaan het, is waar, maar dat dit besig was om van die mees gevorderde onderwysfasiliteite vir Swartes in Afrika te word, is ook 'n feit.

Met die politieke veranderings na die sogenaamde nuwe Suid-Afrika toe, word ook die onderwysheleid na 'n onstabiele saak verander, want dit is 'n algemeen-er- 
kende beginsel dat die onderwys in noue samehang met ander staatkundige strukture moet funksioneer. Daarom is sekere verstellings aan die onderwys onafwendbaar' (Schoeman 1991:17).

Omdat die eindpunt van die nuwe staatkunde in Suid-Afrika onseker is, is ook die uiteindelike oogmerke met die onderwys vaag.

Vir die huidige is daar die drie nuwe bykomende onderwysmodelle. Dit is 'n bedeling op grond van die huidige Grondwet. Tereg word die vrae gevra:

(M)aar wat gaan gebeur as 'n nuwe Grondwet aanvaar word? Wat bedoel die regering daarmee as hy sê dat die laaste woord oor die onderwys nog nie gespreek is nie - is hierdie nuwe era in blanke onderwys (van die drie bykomstige modelle - H G v d W) dan net 'n tussentydse reëling? Wat gaan die regering se oplossing vir die toenemende eis vir 'n enkele onderwysdepartement en 'n nie-rassige toelatingsbeleid in alle skole wees?

(Schoeman 1991:18)

Dit word algemeen so geïnterpreteer dat die modelle-onderwysbeleid bloot tussentyds is: 'Nuwe skoolmodelle wat tans vir oorweging na ouergemeenskappe vir keusetoepassing gegee is, is bedoel om sekere aanpassings wat noodsaaklik geag word, tussentyds te doen' (Volkswag 1990:1).

Sowel die toekomstige Grondwet as die dan geldende onderwysbeleid is in onsekerheid:

Op hierdie stadium is dit moeilik om te sê hoe die nuwe Grondwet in werklikheid daar sal uitsien. Intussen is 'n aantal onderwysmodelle, waaronder die status quo, uitgewerk waaruit een gekies kan word. Dit is egter 'n tydelike reëling, want dit geld net solank die huidige Grondwet nog bestaan....

(Van Staden 1990:11)

Gesię die aandrang op 'n ou humanistiese manifes vir menseregte vir die nuwe Suid-Afrika, gesien die openbare momentum vir die ou politieke rekonsiliasiegesindheid van generaal Louis Botha en gesien die filosofiese aandrang op generaal Jan Smuts se ou holisme, kan die tendens redelik noukeurig geïdentifiseer word.

Veral die verwagting dat onderwys in 'n onomkeerbare drukgang tot 'n nuwe bedeling van ongekwalifiseerde mengskole is, is opvoedkundig uiters ontstellend.

Aan die een kant kan verwag word dat onderwys 'n speelbal in politieke hande sal word. Die gesonde opvoedkundige standpunt is dat 'oor Christelike, moedertaal en kultuurgebonde onderwys moet daar liewer nie onderhandel word nie' (Schoeman 1991:18). Tog het minister Stoffel van der Merwe reeds op 29 Maart 1990 ver- 
klaar 'dat die eis deur swart onderwysinstansies dat 'n enkele, nie-rassige onderwysdepartement sonder enige diskriminasie in Suid-Afrika ingestel moet word, deel sal uitmaak van die onderhandelingsproses vir 'n nuwe Grondwet' (Van Staden 1990: 10).

Daar kan veral van die swart onderhandelaars verwag word dat hulle sekere eise tot mengonderwys selfs as voorwaarde vir die staatkundige onderhandelingsproses sal stel.

Die Soweto Education Crisis Committee (SECC) het reeds op 2 Januarie 1991 in hierdie rigting gewaarsku: 'Die krisis in die swart onderwys kan die onderhandelingsproses vertraag as die Regering nie daadwerklik wys dat hy die krisis wil oplos nie' (Beeld 1991:2).

Aan die ander kant is die keuses wat met die modelle-onderwysbeleid aan ouers gegun word, volgens verwagting 'n bloot tydelike kondisioneringsprogram. 'n Skool wat nie die vereiste minimum stempersentasie vir 'n bepaalde keuse volgens die modelle in 'n sekere jaar behaal het nie, kan in 'enige daaropvolgende jaar weer 'n meningspeiling hou' (Patriot 1991:16).

Dr Van Zyl, uitvoerende direkteur van die Onderwysstigting in Natal, sê dat alle regeringskole in die nabye toekoms oop skole sal wees: 'Die drie modelle wat nou vir skole voorgestel word is 'n voorbereiding om kulture verdraagsamer teenoor mekaar te maak; iets wat in die huidige onderwysbedeling jammerlik agterweë gebly het' (Transvaler 1991e:4).

\subsection{Die modelle}

Die volgende aanhaling gee die kern van die drie bykomstige modelle vir onderwysvoorsiening weer (Inligtingsdokument):

\section{Inleiding}

Die bestaande skoolstelsel sal binne die bepalings van die huidige Grondwet bly voortbestaan...In aansluiting by die behoefte van sekere skoolgeme.nskappe om 'n groter seggenskap te hê in die toelatingsbeleid van hul skole, is daar besluit dat enige skoolgemeenskap, wat dit sou verkies, die Minister kan versoek om hul bestaande gewone openbare skool om te skakel na een van die volgende bykomstige modelle:

- 'n private skool wat na sluiting van die openbare gewone skool in dieselfde geboue bedryf word (later Model A);

- 'n openbare gewone skool wat binne die bepalings van die Grondwet sy eie toelatingsbeleid bepaal (later Model B); 
* 'n openbare gewone skool wat tot 'n staatsondersteunde skool verklaar word (later Model C).

Elke gemeenskap wat op 'n bykomstige model besluit, moet die konsekwensies van so 'n besluit deeglik onder oë neem, aangesien so 'n besluit nie ligtelik ongedaan gemaak sal kan word nie.

\section{Stempersentasie ten gunste van verandering}

'n Gemeenskap wat 'n verandering oorweeg moet 'n meningspeiling aan die hand van vaste voorgeskrewe prosedures hou en sy voorkeur aan die hand van 'n oortuigende meerderheidstem aan die Minister stel. 'n Minimum persentasie van $72 \%$ van al die stemgeregtigdes moet ten gunste van verandering stem, op voorwaarde dat minstens $80 \%$ van al die stemgeregtigde ouers/ wettige voogde aan die stemming deelneem....

\section{Faktore wat in gedagte gehou moet word}

3.3 ...die moedertaal van die leerling (is) die amptelike taal van onderrig, dit wil sê Afrikaans of Engels, en indien die skool diens aan ander lewer, bly die taalmedium van die skool onveranderd.

\subsection{Kultuurgebonde onderwys}

Enige leerling wat hom/haar by 'n skool onder beheer van die Administrasie: Volksraad inskryf, word onderrig aan die hand van die goedgekeurde kurrikulum wat as uitgangspunt die kultuur van die teikengroep het, maar wat eweneens aanraking en bekendstelling met 'n wyer kultuurwêreld omvat....

3.7 Behoud van die waardes en etos van 'n bepaalde skool

Verandering in die toelatingsbeleid van 'n skool mag nie afbreuk doen aan die tradisionele waardes en etos van 'n skool nie.

\subsection{Koshuise}

- Aangesien skoolkoshuise 'n integrerende deel van die opvoedingsprogram van sommige skole vorm, sou enige verandering aan toelatingsbeleid ook toelating tot skoolkoshuise impliseer.

\section{Altematiewe onderwysvoorsiening...}

Die Provinsiale Onderwysdepartement sal voorsiening maak vir alternatiewe onderwysvoorsiening vir dié leerlinge wat vanweë die meerderheidstem ten gunste van 'n alternatiewe model die skool wil verlaat. Die alternatiewe voorsiening sal die mins moontlike ontwrigting vir die leerling en sy ouers 
meebring, maar impliseer skoolbywoning by 'n ander skool wat dan moontlik koshuisinwoning nodig sal maak....

\section{Drie bykomstige onderuysmodelle}

Slegs skoolgemeenskappe wat verandering oorweeg en nie met die status quo tevrede is nie, oefen 'n keuse ten opsigte van een van die volgende modelle uit. Skole wat nie verandering oorweeg nie, gaan nie tot 'n stemming oor nie. 'n Besluit in dié verband word deur die Bestuursraad geïnisieer....

7.1 Privaatskole wat tot stand kom na die sluiting van staatskole (Model A)....

7.1.3.1 'n Subsidie van 45\% vir bedryfskoste word per formule soos aan bestaande privaatskole toegestaan.

7.1.3.2 Die 45\%-subsidie word ingefaseer oor 3 jaar met $85 \%$ in die eerste jaar, $70 \%$ in die tweede jaar, $55 \%$ in die derde jaar en $45 \%$ in die vierde jaar.

7.1.3.3 Die bedryfsuitgawes sluit die salarisse van al die personeel asook voorrade en dienste, instandhouding van geboue en toerusting (indien van toepassing) in.

7.1.3.4 Indien die ouer/skoolgemeenskap die huidige standaard en dienste van die staatskool wil handhaaf teen die huidige vlak van befondsing van staatskole, sal die ouer/skoolgemeenskap by beraming ongeveer R2 520 per leerling per jaar moet bydra, maar die bedrag kan van skool tot skool wissel...

\subsubsection{Implementeringsdatum}

Hierdie model sou op 'n datum soos bepaal in die loop van 1991 geïmplementeer kon word.

7.2 Staatskole wat hul toelatingsbeleid wil verander (Model B)

7.2.1 Indien 'n gemeenskap met die vereiste meerderheid verkies dat die bestuursliggaam van die skool self die toelating van leerlinge bepaal....

\subsubsection{Implementeringsdatum}

Indien die Minister toestemming verleen, sou hierdie model vanaf 1 Januarie 1991 of op 'n later datum geimplementeer kon word.

7.2.4 Finansiële implikasies

Hierdie model hou geen verdere finansiële implikasies vir die ouer/skoolgemeenskap in nie. 
7.3 Staatsondersteunde skool (Model C)

'n Openbare gewone skool wat na sluiting as 'n staatsondersteunde gewone skool gestig word, is vergelykbaar met die huidige staatsondersteunde inrigtings soos pre-primêre en skole vir buitengewone onderwys....

Die volgende beginsels geld:

7.3.1 Beheer en bedryf van die skool.

7.3.1.1 Die bestuursraad ontbind en die skool word deur 'n bestuursliggaam bedryf.

7.3.1.2 Die hoof is as uitvoerende beampte lid van die bestuursliggaam en hy is ' $n$ rekenpligtige beampte.

7.3.1.3 'n Borgliggaam kan aangestel word.

7.3.1.4 Die bestuursliggaam van 'n staatsondersteunde skool

- het 'n eie regspersoonlikheid;

- bestuur die skool se fondse selfstandig, maar onderhewig aan onafhanklike ouditering;

- beheer en bestuur die skool volgens wetgewing;

- se samestelling word deur die Minister voorgeskryf;

- bestaan uit verteenwoordiges van die (ouer)-gemeenskap en ander lede wat deur die Minister aangewys is;

- stel onderwysers op die vlak van Posvlak 1 aan;

- stel administratiewe personeel aan;

* bepaal onderriggelde;

* genereer verdere fondse en ontvang skenkings;

* is verantwoordelik vir die instandhouding van fisiese geriewe, asook bepaalde funksies rondom kapitaaluitgawes.

7.3.2 Finansiële implikasies

7.3.2.1 'n Subsidie wat die volle salarisse slegs van personeel binne voorgeskrewe norme dek, word betaal. Dit bedra ongeveer $75 \%$ van die bedryfsuitgawes. Die oorblywende fondse moet deur die bestuursliggaam self gevind word.

- 7.3.2.2 Die bestuursliggaam verkry, benewens van die Staat, ook fondse van 'n borgliggaam en/of deur skoolfondse, soos deur hom bepaal.

7.3.2.3 Die bydrae van die ouer/gemeenskap/borgliggaam sal tans by beraming ongeveer $\mathrm{R} 900$ per leerling per jaar wees, maar kan van skool tot skool wissel. 


\subsubsection{Personeelaangeleenthede}

7.3.3.1 Die personeel verbonde aan 'n staatsondersteunde onderwysinrigting is op die diensstaat van die Departement en deel derhalwe in die diensvoorwaardes wat vir die personeel in die staatsonderwyssektor geld.

7.3.3.2 Die bevoegdheid om iemand by ' $n$ staatsondersteunde skool aan te stel, te bevorder of te ontslaan, berus by die bestuursliggaam, onderworpe aan die voorafverkreë toestemming van die Minister.

7.3.4 Fisiese fasiliteite

7.3.4.1 Bestaande geboue en terreine word kosteloos aan die beheerliggaam oorgedra, met ' $n$ terugvalkJousule indien die inrigting sou ophou om te bestaan. Die bestuursliggaam is verantwoordelik vir instandhoudingsdienste en uitgawes verbonde aan kapitaalwerke, versekering ensovoorts.

7.3.5 Toelating van leerlinge

Die bestuursliggaam laat leerlinge toe volgens kriteria wat hy self stel binne die bepalings van die Grondwet en ander voorwaardes soos moedertaalonderrig.

\subsubsection{Datum van implementering}

Aangesien die implementering van hierdie model wetswysiging behels, sal dit nie reeds aan die begin van 1991 geïmplementeer kan word nie, maar so vroeg moontlik daarna....

\subsection{Algemene opmerkings}

$\mathrm{Vyf}$ algemene opmerkings is in verband met die modelle-onderwysbeleid op die oomblik van belang.

\subsubsection{Modelle is tydelik}

Eerstens moet steeds in gedagte gehou word dat hierdie beleid slegs geld solank die huidige Grondwet geld. Dit word slegs as 'n oorgangsfase gesien:

Mel Holland, 'n woordvoerder van die NECC (National education coordinating committee), sé...dat die oopstelling van alle skole aangemoedig moet word, veral omdat hulle verstaan dat dit deel moet vorm van die proses om 'n enkele stelsel vir die Departement van Onderwys te vind.

(Transvaler 1991a:3) 


\subsubsection{Modelle in volle vaart}

Tweedens moet opgemerk word dat meer as $10 \%$ van die provinsiale skole sommer reg aan die begin in terme van die modelle-onderwysvoorsiening hulle in Januarie 1991 oopgestel het:

* Die landwye oopstelling van 205 uit sowat 2000 blanke provinsiale skole vir alle rasse is van môre af in die Transvaal van krag te midde van toenemende kritiek....

- Dr Chris Pretorius, die hoof van inligting by die Departement van Onderwys en Kultuur in Pretoria, sè 33 provinsiale skole in Transvaal, een in die Vrystaat, 107 in Kaapland en 64 in Natal het besluit om hulle deure vir alle rasse oop te stel (Transvaler 1991a:3).

\subsubsection{Modelle is verwarrend}

Derdens moet daarop gewys word dat nie almal eenstemmig is oor die interpretasie van die verskillende modelle nie. Dit is nie meteens duidelik wat presies al die verskille tussen die modelle is nie en wat al die implikasies van elke model is nie.

Die voorsitter van die Transvaalse Afrikaanse Ouervereniging (TAO), dr Van Deventer, meen dat van model $B$ nie as oop gepraat kan word nie: 'Ouers wat die sogenaamde skoolmodel B kies, kan ook besluit dat die skool slegs vir Blankes gereserveer word en om na model B-skole as oop skole te verwys, is verkeerd' (Transvaler 1991b).

Aan die ander kant is die gedagte dat indien 'n ouergemeenskap volgens model $B$ besluit om ' $n$ mengskool te word, kan dit dus ook 'n oopskool word. Die Afrikaanse Ouervereniging (AO) sê by monde van sy voorsitter, ds Van Rensburg, dat 'die status quo, dit wil sê blanke staatskole, gehandhaaf moet word' (Patriot 1990).

\subsubsection{Modelle is liberalisties}

Vierdens moet ook kennis geneem word dat nie alle Swartes bereid is om na bestaande blanke skole te gaan nie:

- Die Pan African Student Organisation het gister 'n beroep op swart leerlinge gedoen om hulle nie by blanke skole te laat inskryf nie;

- Hy sê die oopstelling van dié instansies vir ander rasse is 'n liberale slenter om die militantheid van swart kinders te onderdruk;

- Die organisasie sê ook dit is futiel vir swart kinders om by dié skole in te skryf, omdat die onderwys daar vir blankes ontwerp is (Transvaler 1991d:2). 


\subsubsection{Vier modelle}

In die vyfde plek moet ouers daarop let dat indien hulle deur hulle skool opgeroep word om in terme van die modelle te stem, hulle 'n keuse tussen vier moontlikhede moet maak. Hulle moet daarop aandring dat al vier moontlikhede ewe duidelik op die stemgeleentheid gestel word. Daar is 'n keuse nie net tussen die drie bykomende modelle nie maar ook om die status quo van die blanke staatskool te handhaaf.

\section{DIE KRISIS VIR CHRISTELIK-NASIONALE ONDERWYS}

\subsection{Probleme en besware}

Probleme en besware teen mengskole spruit, opvoedkundig gesproke, veral uit die bedreiging van die Christelik-nasionale onderwysbeginsel. Die Christelik-nasionale karakter van die onderwys sal met so 'n stelsel verdwyn (Van Staden 1990:11).

\subsubsection{Getalleverhouding}

Die probleem word vererger omdat blanke leerlinge 'n vinnige dalende neiging toon terwyl swart leerlinge 'n skerp stygende neiging vertoon. Dr Schoeman, 'n opvoedkundige, stel dit as 'n realiteit: '...die dalende neiging in die Afrikanerleerlinggetalle en die gepaardgaande onbenutte [en onderbenutte] klaskamers' (Schoeman 1991: 18).

'n Gemiddelde jaarlikse daling van 4944 leerlinge vind reeds van 1986 af plaas. Volgens mnr Van Staden van die TOD se kommunikasieafdeling gaan die somtotaal leerling in die Transvaal skaars aan die 486 300-kerf raak, wat nog te sê van verlede jaar se 490000 . Met die skole wat gister heropen het, was daar vanjaar (1991) vir die eerste keer ' $n$ aansienlike daling in graad eenleerlinge.

Verlede jaar was daar sowat 45981 eerste innames terwyl dit vanjaar 400 minder is.

Volgens mnr Van Staden word die matriekgetalle vanjaar op 33000 beraam. Dit is meer as ' $n$ duisend matrieks minder as in 1990.

(Transvaler 1991c)

Met die uitbreiding van skoolplig na die swart bevolking, vind 'n fenomenale toename van swart leerlinge plaas: 'Die swart leerlinge alleen sal teen 2000 tussen 9 en 10 miljoen [van 'n totaal van 11,5 miljoen] wees' (Spengler 1988:160).

Die begin van mengskole op welke voorwaardes ook al, van byvoorbeeld 'n minimum van $50 \%$ Blankes, is die begin van 'n instroming en gesien die politieke ontwikkelinge, oorstroming van Blankes deur Swartes. 


\subsubsection{Ouderdomverskil}

Baie jong blanke dogtertjies sal saam met veel ouer swart seuns moet skoolgaan en in die koshuise bly: 'Dit is 'n algemene verskynsel dat baie Swartes eers op 10 tot 12 jaar skool toe gaan. Blanke skooldogters kan dus saam met swart seuns wat vier of vyf jaar ouer as hulle is in dieselfde klaskamer sit' (Pienaar, Basson \& Strauss 1987: 45).

Die sosialisering op skool en koshuis van mengskole sal 'n groter wordende persentasie integrasie tot gevolg hê wat die volkseie op 'n glybaan sal afskaal. Omdat die ouderdomfase van leerlinge hulle volkome oopstel vir invloede, sal die integrasie as normale onderdeel van opvoeding ervaar word. Selfs op tersière onderwysvlak het ons voorbeelde uit die hoogste kringe van gemengde liefdesverhoudings (Rapport 1991:1). 'Voortdurende blootstelling van kinders van verskillende rasse aan mekaar laat die andersheidsbewussyn uiteindelik in so 'n mate afstomp dat liefdesverhoudinge en ondertrouery die noodwendige resultaat is' (Pienaar et al 1987: 46).

\subsubsection{Seksuele molestering}

Omdat die swart seuns veel ouer as die blanke dogtertjies sal wees en omdat baie Swartes tradisioneel 'n ander beskouing en benadering as blanke Christene en Afrikaners tot seks het, kan baie seksuele wanpraktyke, met die implikasies van vigs en so meer wat daarmee gepaard gaan, verwag word.

Seksuele wanpraktyke in gemengde skole sal nie uitbly nie. In die eerste instansie word voorhuwelikse geslagsomgang tradisioneel nie as 'n onsedelike daad by die meeste swart stamme beskou nie. In verwesterde omstandighede waar ouerlike dissipline grootliks in duie gestort het, is dit eerder die reël as die uitsondering.

(Pienaar et al 1987:45)

Hierdie gevaar van seksuele wanpraktyke is nie blote teorieë nie, maar die situasie van gemengde skole in Swaziland gee die volgende voorbeelde:

Twee honderd blanke meisies tussen 10 en 16 jaar van 'n groot aantal skole is (in 'n ondersoek) betrek. Van hulle het 187 erken dat hulle of ingestem het om geslagsgemeenskap met Swazi's by die skool te hê of dat hulle verkrag is. Ses en tagtig het beweer dat hulle verkrag is nadat hulle geweier het om by die skool deel te neem aan geslagsgemeenskap met ander kinders of onderwysers.

Van hulle het 173 gesê dat hulle baie keer, dikwels met verskillende seuns, by dieselfde geleentheid gemeenskap gehad het. Dié wat nie 
wou toestem nie, is met geweld gedreig as hulle nie sou toegee aan die eise van hulle klasmaats of onderwysers nie, of as hulle die aangeleentheid enigsins sou rapporteer.

Van die dogters het 49 erken dat hulle seks by verskeie geleenthede met een of meer Swazionderwysers by die skool gehad het. Dit blyk dat die meeste van hierdie kinders reeds vanaf hulle twaalfde tot veertiende jare gemolesteer word, terwyl die jongste aanranding reeds op agt plaasgevind het.

Die kinders beweer dat hulle deur hulle Swazi-klasmaats as 'sussies', 'rassiste', 'lafaards' of 'koud' genoem word as hulle weier....

Van die kinders moes toekyk terwyl hulle klasmaats gemeenskap het, waarna van die meisies met geweld ontklee en vasgehou is terwyl dieselfde Swazi's die daad met hulle herhaal. Een dogter is so geforseer toe sy 12 was en het sedertdien gewillig seks beoefen met twee of drie seuns terselfdertyd en meer as 200 keer die afgelope twee jaar. Slegs 12 meisies het met blankes seuns omgang gehad.

Van die ouers het al besware by die Swazilandse polisie ingedien, maar die het later laat weet dat die dogters 'verward' is en dat hulle die Swazi's of die onderwysers verlei het.

Hierdie skokkende gebeure vind plaas in gemengde skole. Swartes van 16 jaar en ouer is in dieselfde klas as Blankes van 10 tot 12 jaar.

(Die Afrikaner 1990c:5)

\subsubsection{Mengpersentasie}

Behalwe dat daar in die nuwe Suid-Afrika vir die mengskole waarskynlik naderhand 'n minimum persentasie swart leerlinge in elke skool of klas sal moet wees, sal daar reeds vooraf ook die aandrang of vereiste wees dat 'n minimum persentasie swart onderwysers by elke skool aangestel moet word.

\subsubsection{Leerplanne}

Die leerplanne van mengskole sal inhoudelik die Christelik-nasionale karakter totaal verloor.

\subsubsection{Afrikaans}

Wat die taalmedium betref sou Afrikaans as moedertaal miskien tot min of meer op ouderdom 12 jaar behoue bly maar daarna (of reeds vantevore) sal een van baie tale, so nie Engels nie, die medium wees. Dat Afrikaans reeds in die huidige normale verwikkelinge 'n swak prognose het, blyk uit wetenskaplike studie (Spengler 
1988:154, 165, 168, 203 e a). Afrikaans, Afrikaansheid, Afrikanermentaliteit, Afrikanerskap en die Afrikanervolk sal moet plek maak vir die nuwe van 'n ander nasie.

\subsubsection{Geskiedenis}

Daarom sal en word ons geskiedenis herskryf. Geskiedenisleerplanne sal by die nuwe Suid-Afrika moet aanpas. 'n Voorbeeld van 'n geskiedenisboek wat feitlik alle sonde, misdaad, negatiwiteit en tekortkominge aan Blankes in Suid-Afrika toeskryf en Swartes as bekwames, ondernemende boere, maar verdruk en verontreg, voorhou, is die Readers Digest se The Real Stony: Illustrated History of South Africa (Saunders 1989:1-512).

\subsubsection{Godsdiens}

Ten opsigte van godsdiens sal dit nie net die Christelik-nasionale gees wees wat verdwyn nie, maar ook dié tipe onderwyser èn die inhoud van leerplanne. Vir sover daar nog van Christelikheid in die mengskole sprake sal wees, sal dit waarskynlik'n oppervlakkige en die gekontamineerde Christelikheid van die ideologiese teologieë onder Swartes en hulle tradisionele gelowe wees. Die Afrikaner se reformatoriese erfenis en Calvinistiese inslag sal tot 'n gesosialiseerde spiritualiteit gedwing word.

\subsubsection{Boikotte}

Die bekende boikotstelsel by swart universiteite en swart skole wat elke jaar tot maande se agterstande lei en tot brandstigting, roof en moord, sal gewis op mengskole plaasvind. Die belaglikste beskuldiging van rassisme sal as rede tot boikot gebruik word (Coetzee sj:15). Die bewussyn van diskriminasie kan tot die gekheid gevoer word: 'Several years ago Tanzania decided to pass all examinees, declaring that it was "unfair" to discriminate on the basis of ability" (Patriot Review 1991:iii). Op hierdie wyse word ongekende probleme in ons skole ingevoer. Ook dit, saam met ander oorsake, sal tot ingrypende verlaging van skoolstandaarde lei. Daar sal maar net gepoog word om volgens prof Retief, rektor van die Vrystaat Universiteit nie laer as die internasionale minimum-standaard te daal nie (Transvaler 1990).

\section{EIE WEG AS UITWEG}

\subsection{Kerk en onderwys}

Soos reeds aanvanklik gesê, het die kerk belang by die onderwys. Die kinders van huisgemeentes en kinders van ander huise waaruit dieselfde volk ontstaan, is immers in die onderwys die essensiële komponent. Die religieuse grondmotief is die diepste en belangrikste in alle opvoeding en onderwys. In die Hervormde Kerk se Kerkwet $(1989: 4,36)$ lui artikel X.2: 
Kragtens sy roeping om die lewens volgens die beloftes en die wil van God in te rig, is die Kerk medeverantwoordelik vir die opvoeding van en die onderwys aan die jeug van die hele volk in 'n Christelik-nasionale gees, in huisgesin en skool.

\section{Bepaling 57}

Die Kerk waak oor die opvoeding en onderrig van die jeug van die Kerk en die volk.

Die Kerk stel daarom ook 'n Raad vir Opvoeding en Onderwys volgens Reglementebundel 5.3.1 saam. Dit lui soos volg (Agenda 1989:567):

\section{Samestelling}

\subsubsection{Die Raad}

5.3.1.1.1 bestaan uit sewe lede en word driejaarliks deur die Kommissie van die Algemene Kerkvergadering benoem;

5.3.1.1.2 by 'n tussentydse vakature vul die Kommissie van die Algemene Kerkvergadering die Raad op voordrag van die Raad self aan, en

5.3.1.1.3 kan met goedkeuring van die Kommissie van die Algemene Kerkvergadering, sy ledetal met kundige persone aanvul tot 'n maksimum van tien lede.

\section{Opdrag}

\subsubsection{Die Raad}

5.3.1.2.1 stel deurlopend ondersoek in na die inhoud en betekenis van die Christelik-nasionale karakter, die beleid, die algemene ontwikkeling en die funksionering van die onderwysvoorsiening,

5.3.1.2.2 gee aan die Kerk voorligting in alle sake wat die formele, informele en nie-formele opvoeding en onderwys aangaan,

5.3.1.2.3 gee voorligting aan ringsrade en kerkrade ten opsigte van hulle taak,

5.3.1.2.4 begelei ouers ten opsigte van hulle betrokkenheid en verantwoordelikheid by binne- en buitemuurse skoolaangeleenthede,

5.3.1.2.5 stel deurlopend ondersoek in na die algemene stand van die informele Christelike opvoeding met die oog op voorligting aan die Kerk en ouers,

5.3.1.2.6 begelei ouers met die informele Christelike opvoeding van hulle kinders,

5.3.1.2.7 skakel met ander rade en kerke met die oog op 'n gemeenskaplike strategie, en 
5.3.1.2.8 gee in samewerking met ander rade aan die Kerk voorligting oor die plek van die nie-belydende lidmaat in die werk van die Kerk.

Werkwyse

\subsubsection{Die Raad}

5.3.1.3.1 benoem by sy eerste sitting 'n voorsitter, 'n vise-voorsitter en sekretaris, vergader minstens twee keer per jaar, hou notule van die verrigtinge en besluite van die vergaderings,

5.3.1.3.4 publiseer saam met ander rade van die Kerk en KITAL toerustingsmateriaal, en

5.3.1.3.5 lewer jaarliks verslag aan die Kommissie van die Algemene Kerkvergadering.

Die Ringsvergadering het ook volgens bepaling $8 . X 1$ tot taak om 'n ringsraad vir opvoeding en onderwys te benoem (Kerkwet 1989:16).

Tereg sê Van Wyk aan die een kant dat hierdie Kerkwet 'n weerklank van 'n 'teokratiese verbondsopvatting' het, en aan die ander kant dat hierdie opvatting 'al meer in die branding [gaan] kom soos die neutrale owerheid met sy skole al verder weg sal beweeg van die Christelik-nasionale beginsel...'(Van Wyk 1989:310, 311).

Dat die Hervormde Kerk nie maar net genoemde artikel en bepaling as 'n dooie letter het nie, maar dat die Kerk inderdaad getrou daarmee probeer wees, blyk uit die navorsing van dr H T Van Deventer, die huidige voorsitter van die Kerk se Raad vir Opvoeding en Onderwys (Van Deventer 1985:1-190).

Skrywer het reeds ses jaar gelede op laasgenoemde Raad 'n beroep gedoen dat 'hy wakker en inisiatiefvol [moet] wees om die Kerk as geheel en die lidmate van die Kerk individueel op allerlei wyse voor te lig' (Van der Westhuizen 1986:768). Dit is gedoen na aanleiding van die feit dat die Hervormde Kerk aanpassings in die uitvoering van sy beleid moet maak soos die nood van omstandighede vereis. Van Deventer (1985:47) dui aan dat omstandighede onder die Engelse oorheersing na die Tweede Vryheidsoorlog, van so 'n aard was dat selfs die Hervormde Kerk, wat Christelik-nasionale onderwys voorstaan, tydelik as 'n noodmaatreël ook die CNOskole bevorder het:

Soos die Engelse die kampskole imperialisties wou misbruik, moes die Afrikaner private skole gebruik om iets van Christelik-nasionale onderwys tot sy reg te laat probeer kom. Is ons nie vandag vinnig op pad na so 'n noodtoestand nie?

(Van der Westhuizen 1986:767) 


\subsection{Soeke na 'n eie weg}

\subsubsection{Privaatskole}

Behalwe die politieke weë om moontlik in die huidige ontwikkelende situasie tog op een of ander wyse die verlangde Christelik-nasionale onderwys te handhaaf, en behalwe die politieke weg om eie onderwys in 'n moontlike gepartisioneerde Afrikanerland te implementeer, bly daar die opsie van privaatskole oor.

In die VSA was dit ook die uitweg, 'n duur uitweg:

In elf suidelike state is daar tussen 1965 en 1970 nie minder nie as 700 privaatskole gestig...As die onkoste verbonde aan die bywoning van 'n privaatskool nie so hoog was nie, sou veel meer leerlinge sulke skole bygewoon het. In 'n ondersoek by skole in sewe distrikte in Florida is gevind dat twee derdes van die ouers wat desegregasie (integrasie H G v d W) wou ontduik daarvan afgesien het, omdat dit te duur was.

(Louw 1983:15)

\subsubsection{Twee kategoriē}

Onder privaatskole kan twee kategorieë verstaan word: staatsprivaatskole en onafhanklike privaatskole. Onder 'staatsprivaatskole' kan van die modelle wat reeds bespreek is, verstaan word. Vir sover sulke skole in die nuwe Suid-Afrika 'n plek sou kon kry, moet daar betyds en deurtastend daarvoor beywer word. Omdat staatsprivaatskole waarskynlik as staatsondersteunde apartheid gesien sal word, is die moontlikheid van 'n permanente bestaan daarvan in die verwagte nuwe bedeling gering.

Onafhanklike privaatskole het, behalwe die finansièle, fasiliteite en organisatoriese probleme, veral die groot probleem van erkenning deur die staat. Omdat enige staat skoolplig en/of leerplig moet afdwing, is die vraag of die nuwe owerheid die onafhanklike privaatskole onder sy skoolplig- en leerpligregulasies sal erken. Die leerplan sal dalk ook aan bepaalde vereistes ten opsigte van leerinhoude moet voldoen.

In die VSA is die stigting van privaatskole, soos byvoorbeeld deur die New Christian Right wat kinders tuis laat skoolgaan, bevoordeel deur die feit dat die VSA en Kanada nie skoolplig het nie maar wel leerplig (Van der Walt 1990:186). In die VSA leef die gedagte in sommige kringe baie sterk dat 'the home-school movement is where the true Christian revival is taking place...Handing one's children over to the humanists for education is tantamount to handing them over to Satan' (Blumenfeld 1990:2, 3).

In Suid-Afrika is die neiging om skoolplig van sestienjarige ouderdom te verminder na veertien jaar of standerd vier. Leerplig duur dan nog langer. Indien die 
doel van Christelik-nasionale onderwys nie met staatsprivaatskole bereik kan word nie, moet op onafhanklike privaatskole en leerpliginrigtings gekonsentreer word. Indien leerpliginrigtings (in die private, openbare en staatsektore) hom nie leen om die doel van Christelik-nasionale onderwys te realiseer nie, sal ook vir hierdie ouderdomsgroep op onafhanklike privaatskole gekonsentreer moet word. Indien onafhanklike privaatskole vir skoolpligtiges nie toegelaat sal word nie, of nie wat hulle leerinhoude en onderwysgees betref, toegelaat sal word nie - want mnr Albie Sachs, regsadviseur van die ANC sê: 'Don't privatise apartheid' (Financial Mail 1990) - sal die eie weg alleen maar van toepassing gemaak moet word op 'buitemuurse' onafhanklike privaatskole vir alle ouderdomsgroepe van skool- en leerpligtiges.

Huisskole met die oog op Christelik-nasionale onderwys wat reeds op voetspoor van die Amerikaanse voorbeeld in Suid-Afrika opgerig is, ontmoet in die huidige bedeling geweldige weerstand. So 'n skool is die Paul Kruger Gereformeerde Volkskool (PKGV) in Pretoria (vgl Die Afrikaner 1990a; 1990b). Hierdie huisskool het ontstaan op grond van 'n regulasie wat 'n huisskool toegelaat het indien daar minder as twintig kinders is. Hierdie regulasie is in Junie 1990 egter opgehef. Nou moet daar meer as twintig leerlinge wees. Die skool moet geregistreer wees en moet voldoen aan vereistes ten opsigte van oppervlakte, geriewe, toilette, onderwyskwalifikasies en so meer.

\subsection{Noodsaak vir 'n eie weg}

Of die eie weg nou 'n uitweg vir die skool- en leerplig is of 'n buitemuurse omweg bykomend by die staatsvereistes, die feit bly staan dat dit hoë eise aan die Kerk, die volk en die betrokke ouergemeenskap gaan stel.

$\mathrm{Na}$ die Tweede Vryheidsoorlog het die Afrikaner ook 'met die grootste persoonlike opoffering deur leerkrag, leerling en ouer' volkseie onderwys en moedertaalonderrig in die lewe geroep (Basson 1990:2).

Indien Christelik-nasionale onderwys vir ons die essensiële element is wat ons Kerk en volk altyd daaraan geheg het, sal uitgawe, opoffering en moeite beloon word. Wanneer mengskole die enigste staatserkende en staatsondersteunde skole sal wees, sal opvoeding in Christelik-nasionale gees volledig uitgewis wees in die staatsonderwys: 'Van ware opvoeding waar daar voorsiening gemaak word vir eiesoortigheid van verskillende rasse, volke, kulture kan daar geen sprake wees waar ekonomiese oorwegings van so 'n deurslaggewende belang is nie' (Louw 1983:79).

Buitendien gaan opvoeding grootliks tot niet in enige onderwys wat bloot op ekonomiese beginsels gebaseer word. Die ekonomiese basis word reeds al meer die vernaamste in die onderwys: 'Die standpunt word ook gehuldig dat die onderwys en 
tegnologiese beleid in die toekoms al meer by die ekonomiese struktuur moet inpas' (Spengler 1988:173).

Die Christelik-nasionale grondmotiewe in die opvoeding word deur ander determinante of dryfkragte in die onderwys soos ekonomiese, demografiese en teg. nologiese vervang (Spengler 1988:151).

Omdat Christelik-nasionale opvoeding waarskynlik allerweë uit die onderwys gaan verdwyn, sal die gesin, Kerk en volk die opvoedingstaak op ander wyses as die staatsonderwys georganiseerd ter hand moet neem.

Dieselfde opofferings wat ons voorouers na die Tweede Vryheidsoorlog in CNO moes maak, dieselfde opofferings en toegewydheid wat die Moslemgemeenskap en die Jode maak om buitemuurs die Moslemopvoeding en die Joodse opvoeding by hulle kinders tuis te bring, kan ons ook maak, ook namens die minder gegoede Blankes wat onafhanklike of buitemuurse onafhanklike privaatskole nie heeltemal kan bekostig nie.

\subsection{Buitemuurse onafhanklike privaatskole}

Onderstaande voorstelle ter oorweging tot die implementering van privaatskole is van toepassing op sowel onafhanklike maar staatserkende privaatskole (OSP) as op buitemuurse onafhanklike privaatskole (BOP).

Indien OSP toegelaat word maar met staatsvoorgeskrewe leerplanne, sal die leerlinge met die betrokke leerinhoude deeglik onderrig word maar in Christeliknasionale gees. Indien slegs BOP bestaanbaar sal wees, sal Christelik-nasionale perspektief rondom die staatskurrikula ingebou moet word.

\subsubsection{Kultuurliggame}

Afrikaanse en Afrikanerkultuurliggame, byvoorbeeld die FAK, die nuutgestigte Afrikaner-Kultuurbond, die Afrikaner Volkswag en moontlik ander, kan gesamentlik of een uit hulle die organisasie en administrasie inisieer. Sulke verenigings beskik oor sowel infrastruktuur as teikengerigtheid.

\subsubsection{Kerke}

Die Nederduitsch Hervormde Kerk of enige van die ander kerke, of die kerke gesamentlik, kan die inisiatief neem.

Daar was al interkerklike komitees vir samewerking ten opsigte van byvoorbeeld handboeke vir Bybelonderrig op skool. Daar bestaan die Tussenkerklike komitee (TKK) wat dekades lank oor eenheid gesprek voer en nou geleentheid kan kry om in eenheid op te tree of te laat optree. 
Indien die tussenkerklike onderwysskakeling wat daar reeds is, om een of ander rede nie in hierdie verband effektief kan funksioneer nie, moet 'n ander komitee dit ter hand neem of die Nederduitsch Hervormde Kerk moet alleen die inisiatief neem. Die bestaande ringsrade vir onderwys wat reeds onder leiding van die Kerk se Raad vir opvoeding en onderwys goed op dreef is, is organisatories beskikbaar.

\subsubsection{Lokale}

Die baie kerke, kerksale en veral kategeseskoolfasiliteite kan sonder fenomenale ekstras weeksdae vir BOP ingerig word. In die geskiedenis is voorbeelde volop waar kerkgeboue (toe maar eintlik saalkerke) weeksdae as skoolgeboue gegeld het. Hier en daar kan dit nodig wees om bykomende lokale of partisies op te rig. Dit kan gesamentlik by een kerk deur al die plaaslike meewerkende kerke en die ouergemeenskap bygebring word. Selfs sentrale kerkadministratiewe kantore en personeel kan dalk ook benut word.

Vir sover die kerke se kategeseskole nog op Sondae toegelaat word, maar selfs gén verdere buitemuurse skoolaktiwiteite nie, sal die Christelik-nasionale onderwys met die kategese geïntegreer moet word.

\subsubsection{Hulpmiddels}

Indien daar van bestaande fasiliteite gebruik gemaak sal kan word, soos hierbo genoem, sal die uitgawe vir projektors, swartborde en so meer nie te hoog loop nie. Baie kerke beskik ook reeds daaroor.

Boeke, skryfgerei en ander benodigdhede kan hoofsaaklik deur die leerlinge/ ouers self betaal word - soos dit byvoorbeeld in die Kaapprovinsie nog altyd die geval was.

\subsection{Onderwysers}

Indien die situasie tot volledige mengskole ontwikkel, sal daar baie goed gekwalifiseerde onderwysers wees wat maar te graag by so 'n OSP of BOP onderwys wil gee.

Die leerkragte sal waarskynlik die vernaamste fmansiële pos in so 'n stelsel uitmaak. Daar kan dalk vir hulle mediese en pensioenfondse via die kerke se fasiliteite beding word. Vir salarisse kan 'n gedesentraliseerde stelsel van plaaslike onderhoud of 'n gesentraliseerde onderwysfonds ingestel word. Die opleiding of bykomende toerusting van leerkragte om spesifiek doeleffektief te wees, moet ook oorweeg word. 


\subsubsection{Christelik-nasionale onderwysfonds (CNOF)}

In plaas dat sulke geweldige bedrae geld uit die lidmaat se dankoffer uiteindelik in luukse kerkgeboue, pastorieë of gebouekomplekse vasgemessel word, kan 'n groot deel daarvan in die toekoms in Christelik-nasionale onderwys belê word. Dit kan in 'n Christelik-nasionale onderwysfonds byeen gebring word.

\subsubsection{Korrespondensiekursus}

Indien geen omweg wat ' $n$ werklike uitweg is, bestaan nie, moet 'n korrespondensiekursus onrweeg word.

Die kultuurliggame of kerke of ' $n$ kerk kan dit oorweeg om 'n bestaande korrespondensie-inrigting oor te neem of 'n nuwe op die been te bring en by die Korrespondensiekollegeraad te registreer.

Leerlinge kan dan onder toesig van hulle ouers en met assistensie van die kerk of gemeente self in Christelik-volkseie grondmotiewe toegerus word.

\subsubsection{Christelik-volkseie onderwysliggaam (CVOL)}

Miskien moet ' $n$ gemeente, ' $n$ kerk of ' $n$ kultuurbeweging die inisiatief neem tot die stigting van 'n nuwe Christelik-nasionale onderwysliggaam. 'n Bestaande onderwysliggaam kan straks ook hierop ingestem word. So 'n liggaam se aanvanklike taak kan wees om die beste vir Christelik-nasionale onderwys in die openbaar te beding.

Daarby moet hy hom met studie oor moontlike nuwe weë, soos in hierdie bydrae gepoog, besig hou. Behalwe genoemde inisiatiewe kan die voorgestelde liggaam reeds skoffelwerk in verband met 'n Christelik-nasionale onderwysfonds onderneem.

\section{SEWE OPSIES}

In hoofsaak is daar by wyse van opsomming dus moontlik sewe opsies:

- Die politieke status quo met ontwikkelende volksoewereiniteite.

- Politieke gepartisioneerde Afrikanerland.

- Die handhawing van die status quo-onderwysmodel.

- Handhawing van staatsondersteunde privaatskole (bv onderwysmodel B).

- Buitemuurse onafhanklike privaatskole.

- Christelik-nasionale kategese.

- Korrespondensiële volkseie onderwys. 


\section{Literatuurverwysings}

Algemene Kerkvergadering van die Nederduitsch Hervormde Kerk van Afrika 1989. Agenda met bylaes. Pretoria: Nederduitsch Hervormde Kerk.

Barnard, S S 1985. Kriskras Kruispad. Venster op die Onderwys. Potchefstroom: PU vir CHO.

Basson, J L 1990. Onderwys in die krisis. Veg, Desember 1990.

Beeld 1991. SECC bal vuis oor dié skole. 3 Januarie, 2.

Blumenfeld, S L 1990. The Home-school Movement and Christian revival. Chalcedon Report 302, September 1990, $2,3$.

Coetzee, J C 1969. Die plek van die lewensopvatting in ons onderwysbeleid. ' $n$ Volk besin oor sy opvoeding en onderwys. Pretoria: Interkerklike Uitgewerstrust.

Coetzee, J C N sa (1991). Oop skole: 'n Opvoedkundige studie oor rasgemengde skole. Vredendal: Orion Printers Parow.

Die Afrikaner 1990a. 31 Oktober 1990.

--- 1990b. 7 November 1990.

... 1990c. Gemengde skole onteer blanke dogters. 5 Desember, 5.

Diensboek 1987. Nederduitsch Hervormde Kerk van Afrika. Pretoria: KITAL.

Financial Mail 1990. 25 Mei 1990.

Heyns, A M 1985. Wit, Geel, Bruin en Swart - en die skool. Venster op die onderwys. Potchefstroom: PU vir CHO.

Inligtingsdokument 1990. Bykomstige modelle vir onderwysvoorsiening. Departement Onderwys en Kultuur, Administrasie: Volksraad.

Kerkwet en Bepalings van die Nederduitsch Hervormde Kerk van Afrika 1989. Pretoria: Gutenberg.

Louw, G J J 1983. Opvoeding in 'n veelvolkige samelewing. Pretoria: Oranje-werkers.

Niemann, G S 1985. Die skool gaan huis toe. Venster op die ondenwys. Potchefstroom: PU vir CHO.

Patriot 1990. Skole: AO skop vas. 30 November.

--- 1991. Blanke skole in drukgang tot veelrassigheid: Nee-stem word nie aanvaar nie. 11 Janurie, 16.

Patriot Review 1991. Black Matric Results. 8 Februarie, iii.

Pienaar, J J, Basson, J L \& Strauss F J 1987. Oop skole - gaan ons dit toelaat? Windhoek: Eros.

Rapport 1991. Niks keer ons liefde. 13 Januarie, 1.

Saunders, C 1989. The real story: Illustrated history of South Africa. 2nd ed. Cape Town: Readers Digest.

Schoeman, S 1991. Ons pad vorentoe met Christelik-Nasionale onderwys. Konteks 2/1, 17-18. 
Sprengler, J J 1988. Veranderde ekonomiese en verwante omstandighede in SuidAfrika: Implikasies vir primêre en sekondêre onderwys. M Com-verhandeling, Potchefstroomse Universiteit vir Christelike Hoër Onderwys.

Transvaler 1990. Standaard vir nuwe SA moet laer. 27 November.

--- 1991a. Skole oop te midde van kritiek. 8 Januarie, 3.

--- 1991b. Model B misverstaan. 10 Januarie.

--- 1991c. 1000 minder matrieks in Transvaal. 10 Januarie.

--- 1991d. Swartes moet wegbly van blanke skole. 11 Januarie, 2.

-.- 1991e. Uitweg is private skole. 16 Januarie, 4.

Van der Walt, J H P 1985. Tot hiertoe en hoe verder? Venster op die Onderwys. Potchefstroom: PU vir CHO.

-.- 1990. Boekbespreking: $\mathrm{H}$ van Brummelen. In die Skriflig 24/2, 185-186.

Van der Walt, J L, Dekker, E I \& Van der Walt, I D 1985. Die opvoedingsgebeure: 'n Skrifmatige perspektief. Potchefstroom: PU vir CHO.

Van der Westhuizen, H G 1966. Werklikheidsbesef. Onderwysblad van die Transvaalse Ondenysvereniging en die Natalse Onderwysunie. Augustus, 137-139.

--- 1977. Vertrou op God. Pretoria: HAUM.

.-. 1981. Volksontbening. Leer-en Lewenskwessies in Suid-Afrika. Oktober, 18-36.

..- 1986. Proefskrifbespreking: H T van Deventer. HTS 42/4, 767-776.

Van Deventer, H T 1985. Die begronding van die Nederduitsch Hervormde Kerk van Afrika se Onderwysbeleid 1982-1985. DD-proefskrif, Universiteit van Pretoria.

Van Staden, G C 1990. Die bedreiging van Christelik-nasionale onderwys. Leer-en Lewenskwessies in Suid-Afrika. November, 10-12.

Van Wyk, B J 1989. Die presbiteriaal-sinodale kerkbegrip met besondere verwysing na die Kerkwet van die Nederduitsch Hervormde Kerk van Afrika. DD-proefskrif, Universiteit van Pretoria.

Volkswag, 1990. Op Wag. November/Desember 1990. 